\title{
I am HIV-positive, but I am a human being: qualitative study on experiences of stigma in health care centres in the Islamic Republic of Iran
}

Nasrin Abedinia, ${ }^{1}$ Mehrnaz Rasoolinajad, ${ }^{2}$ Ahmad Noorbala ${ }^{3}$ and Banfsheh Moradmand Badie 4

${ }^{1}$ Department of Infection, Iranian Research Center for HIV/AIDS, Iranian Institute for Reduction of High Risk Behaviors \& Family Health Research Center Maternal Neonatal \& fetal Health Research Center Vali Asr Hospital , Tehran University of Medical Sciences (TUMS), Tehran, Islamic Republic of Iran (Correspondence to Nasrin Abedinia: Nasrin.Abedinia@yahoo.com; Nasrin.Abedinia@gmail.com). ${ }^{2}$ Department of Infection, Iranian Research Center for HIV/AIDS, Iranian Institute for Reduction of High Risk Behaviors, Tehran University of Medical Sciences (TUMS), Tehran, Islamic Republic of Iran. ${ }^{3}$ Department of Psychiatry, Psychosomatic Medicine Research Center, Imam Khomeini Hospital, Tehran University of Medical Sciences, Tehran, Islamic Republic of Iran. ${ }^{4}$ School of Health Sciences, Faculty of Medicine, Nursing and Health Sciences, Flinders University, Adelaide, South Australia, Australia.

\begin{abstract}
Background: People living with HIV can have many health problems and may face difficulties when seeking health care because of stigma and the inappropriate behaviour of health care staff.

Aims: This study aimed to assess the problems people living with HIV face when seeking health care in the Islamic Republic of Iran.

Methods: A qualitative study was conducted with 10 people living with HIV who were members of the positive fellowship club of the Imam Khomeini Hospital in Tehran, Islamic Republic of Iran. Participation was voluntary. Using a focus group discussion, the participants talked about the problems they faced when seeking health care in different health departments and clinics. Data were analysed using inductive content analysis.

Results: The participants faced many problems in all health departments and clinics when seeking health care. The most important problems were: 1) refusal of treatment in outpatient, medical and surgical departments; 2) inappropriate behaviour of consultants and medical staff; and 3) insufficient knowledge of medical staff about HIV and how it is transmitted.

Conclusions: Providing medical and health care staff with more information on HIV and its transmission, training them on proper treatment and management of patients with HIV, and providing free treatment packages and medical services for people living with HIV may help reduce the stigma and problems HIV patients face when seeking health care, and improve the care they receive.

Keywords: HIV infection, health care, social stigma, qualitative research, Iran

Citation: Abedinia N; Rasoolinejad M; Noorbala A; Badie BM. I am HIV-positive, but I am a human being: qualitative study on experiences of stigma at health care centres in the Islamic Republic of Iran. East Mediterr Health J. 2019;25(10):669-676. https://doi.org/10.26719/emhj.19.012

Received: 31/08/15; accepted: 11/12/17

Copyright (C) World Health Organization (WHO) 2019. Some rights reserved. This work is available under the CC BY-NC-SA 3.o IGO license https:// creativecommons.org/licenses/by-nc-sa/3.o/igo
\end{abstract}

\section{Introduction}

In 2016, the Islamic Republic of Iran had an estimated 5000 (1400-13 000) new HIV infections and 4000 (25006200) AIDS-related deaths. There were 66000 (37 000-120 0oo) people living with HIV in $2016,14 \%$ (7-26\%) of whom were accessing antiretroviral therapy. Among pregnant women living with HIV, 51\% (27-> 95\%) were accessing treatment or prophylaxis to prevent transmission of HIV to their children. Less than $100(<100-<500)$ children were infected with HIV through mother-to-child transmission. Of people living with HIV, about $8 \%(5-15 \%)$ had suppressed viral loads (1).

Common but incorrect beliefs can cause rejection of people infected with HIV by their family and community (2). Society's fear of the disease and lack of knowledge of how the virus is transmitted and how transmission can be prevented have affected the care that patients with HIV receive. The stability of HIV outside the body is very low; nonetheless, there is a risk of transmission of infection from HIV-positive patients to health professionals including physicians, dentists, nurses, auxiliary nurses, health workers and hospital staff (3). Because of this and misconceptions about HIV infection, some health personnel may prefer not to treat people with HIV (4). Negative attitudes of medical staff towards the disease and stigmatization of patients with HIV may result in these patients not receiving a diagnosis of the disease or treatment, and they may be deprived of access to other health services. Such discriminatory practices can result in the marginalization of people with HIV and inadequate/poor quality health care for them. This will not only weaken the patient's health but may also lead to a lack of cooperation with medical staff and refusal of treatment which can affect the spread of the disease.

Adequate knowledge about HIV/AIDS is important; it can result in better care for people living with HIV and provide accurate information to the general population (5). Better awareness and knowledge of HIV and more positive attitudes among health care workers can reduce 
their fear of caring for people living with HIV/AIDS and prevent the negative effects that inadequate care can have on these patients and society (3).

Ethical treatment of people living with HIV/AIDS can help control and prevention strategies in communities, such as education and information dissemination, voluntary counselling and testing, harm reduction services, care and treatment of venereal diseases, care of family, and care and treatment of patients (6).

This study evaluated the problems people living with HIV face when seeking health care in the Islamic Republic of Iran. It is hoped that awareness of these problems will allow authorities to plan and implement appropriate measures to resolve them.

\section{Methods}

\section{Study design}

This was a qualitative study using focus group discussions with patients infected with HIV to assess the problems they face when seeking health care in different health departments and clinics.

\section{Participants}

Participants were selected from the positive fellowship club and behavioural diseases counselling clinic of the infectious diseases ward of the Imam Khomeini Hospital in Tehran. The participants were 10 people with HIV who were members of the positive fellowship club (the club has more than 100 members). People living with HIV are referred to the club for support in all aspects of their life by the behavioural diseases counselling clinic. Staff were informed of the study and its objectives and they explained this to the club members and that their voluntary participation in group session was being requested in order to discuss the difficulties they faced when seeking health care in various health departments and clinics. The positive fellowship club was established in 2006 by Dr Mino Mohraz, president of the AIDS Research Centre of Iran, with the financial support of UNAIDS. It aims to empower people living with HIV by helping them find employment. It also organizes recreational and social activities, and provides psychological services to people with HIV who are members of the club.

\section{Data collection}

Data were collected in May 2015 from 10 people living with HIV who agreed to participate. Before starting the session, the participants were asked for and gave permission to use a tape recorder to record their comments. The group discussion was recorded and then transcribed.

\section{Data analysis}

The data were collected through focus group interview. One meeting was held, lasting about two and a half hours. The participants talked about their stigma and treatment problems in different parts of hospital. The group meeting was tape recorded; all the recorded discussions were tran- scribed and used as the source for data analysis. All statements about a given topic were categorized as either from individual or the group. Quotes were grouped into categories and sub-categories. Text of the focus group discussion was analysed using qualitative content analysis. Content analysis is appropriate when there are limited theories or research about the subject under study. In qualitative content analysis, researchers avoid using assumed categories and try to obtain categories from the data instead (7).

\section{Ethical considerations}

This study was approved by the ethics committee of Tehran University of Medical Sciences. Participants were informed that data collection was solely for the purposes of study. Written consent for interviews and recording group discussions was taken from all the participants. All ethical principles were adhered to in relation to confidentiality of the participants' names and protection of audiotapes. Participants were free to withdraw from the study at any time during the project.

\section{Results}

Below, we have summarized some of the experiences and problems our participants and other patients with HIV had when seeking health care in various hospital wards and health care facilities.

\section{Problems in women's and midwifery wards}

\section{Woman infected with HIV by her husband}

This participant explained that women with HIV face many problems in women's and maternity wards in relation to the behaviour of medical staff.

"In the maternity ward, when patients tell staff that they are HIVpositive, staff treat them very badly as if they were criminals. Without consulting the patients, they bring a form and ask them to tick that they do not want to have children. I was admitted myself once because I had bleeding. When they saw in my records that I was HIV-positive, nobody agreed to examine me; nurses thought that I came to the ward and wanted to infect them, so they wouldn't touch me. The behaviour of staff is so bad that patients are psychologically damaged."

\section{Woman infected with HIV by her husband, who used to inject drugs}

"Most HIV patients who come here are young, and they want to marry and have children. If they get married, the midwifery staff ask them, "Why are you going to have kids?" I'm a human and I have the right to live like others and have children."

\section{Problems in internal and endoscopy departments}

\section{Woman infected with HIV by her husband}

"Medical staff say to an HIV-positive patient coming for endoscopy that they can't do the endoscopy because they are HIV-positive, all their equipment would become infected if they did the procedure." 


\section{Young woman infected with HIV by her sexual partner, who injected drugs}

"I am honest and say I am HIV-positive. In the two years that I have had stomach pain, I totally forgot my HIV infection. herever I went, when I said was HIV-positive, the doctors treated me very badly. They told me that I did not need an endoscopy because I had no problem. When I went home, I felt I was dying, the pain was so severe."

\section{Adolescent girl with HIV infected by injecting drugs with friends}

"I needed to do a renal biopsy when I was in hospital. There was a male and a female doctor both with renal expertise. She said, "This person has HIV" and he said it was alright. The male doctor said you didn't need to use gloves with an HIV patient. Both doctors were identically educated but they differed from each other."

\section{Problems in the ophthalmology department}

A young boy living with HIV had had many surgeries in a public hospital because of eye problems. He had been infected by blood during medical treatment in the ophthalmology ward.

"I went to the ophthalmology department and they said that I did not have a problem and they could not remove the sutures from my eye. I felt severe pain in my eye and I said to myself that I would infect as many as people I could. But I didn't, I would be too afraid."

\section{Problems in the surgery ward}

\section{Woman infected with HIV by her husband, who injected drugs}

"Last year my husband had an accident and needed surgery on his back. When I went to see him after surgery, his back was bleeding and the bedding was soaked with blood. He was wearing a surgical gown with torn sleeves and pants. No one touched him. They wanted to bring me gloves; I refused. Some young staff came wearing masks and gloves. My husband said, "I won't let anyone change my clothes and bedding". Wherever I go, I do not say that I am HIV-positive, but the behaviour of others really bothers me.

\section{Young woman with HIV infected by injecting drugs at parties}

"I was dying and had terrible pain. Staff came frequently just to inject morphine; they wanted to shut me up. I had such severe pain that the morphine only relieved me for 5 minutes and then the pain started again. They injected me so many times I vomited and a bucket was put next to me. They wrote, "The patient was discharged in full health." I was still in pain and they sent me out of the hospital. Another hospital would not agree to operate until 9:30/10:00 pm. I was crying from 7 am but they did not take me to the operating room because the doctors were afraid. My mother told them that my disease was controlled and my hepatitis was being treated, so they should not be afraid. In the end, an old doctor came and said it was not important if he died."

\section{Problems in the cardiovascular department Teenage woman infected with HIV by her husband}

"I was infected during pregnancy. After I gave birth to my son, I thought that he had a heart problem and needed surgery. On the last visit, the doctor realized that we were HIV-positive. He threw us out of his office and spoke offensively to us in front of all the patients. He said that our child might be infected. We showed him our son's negative test result but he said we had bribed the laboratory to give us the negative result. After pleading with doctors and after several tests, one of the professors agreed to operate on our son, but I will never forget the behavior of the first doctor."

\section{Problems in dermatology clinics}

Woman infected with HIV by her husband, who injected drugs

"The behaviour of staff in the dermatology clinic is very bad. Medical staff did not touch me in any way. I was itching and the doctor told me my skin was dry. I asked him to examine me and he said there was no need and I should leave. I went to the clinic again and told him that the medication hadn't worked. He said it might be an allergy. I begged him to examine me; he said this was the skin and we had to try different medications to find the cause. Finally, I told him that I was using [an immunomodulator drug]. He said that my skin condition might be due to this drug. Doctors do not examine at all."

\section{Problems in dental clinics}

Young woman infected with HIV by her sexual partner, who injected drugs

"I went to the dentist, paid a lot of money and said I was infected with HIV. Many of my friends told me not to say that I had AIDS. I think they are right."

\section{Problems at clinics for behavioural and infectious diseases}

Young man infected with HIV through contaminated blood during a transfusion in hospital

"I was hospitalized in the infectious diseases unit and the behaviour of the staff was terrible. I wanted to throw myself out of the window. Some staff tied my hands and I was totally naked. When the head nurse was taking blood from me, I was shivering and they said I was an addict. One of the nurses said I should be taken to the welfare department and they would inject me with something and would get rid of me. Everybody who worked there said such things, even the consultant. There was no counselling. The first day I met with the consultant, I sat in the wheelchair and she hit the table with her hand and shouted loudly (her voice is still in my ears), I was quite woozy and confused."

\section{Woman infected with HIV by her husband}

She describes the experience of when her husband, who died 10 years ago, was hospitalized.

"My husband was admitted to the infectious unit of this hospital and the personnel mistreated him. It is much better now compared to 12 years ago. The behaviour then was so bad that I used to change the bedding, curtains and clothes of my husband and clean his room."

\section{Young woman infected with HIV by her partner, who injected drugs}

"It seems that everything on the Internet is wrong, and even information here [in the clinic]. I respect the consultant here but inside I hate her as she has a terrible behaviour. I noticed that the staff always wear gloves. I thought they had the right to do so and I was wearing gloves in the house when I wanted to do 
something. I did not know [there is no need for wearing gloves], but if they [staff] do not know, then they should not work here. Why are they wearing gloves? This behaviour is because of fear, I know."

\section{Woman infected with HIV by her husband}

She is a consultant at positive fellowship club; she describes her experience of dealing with patients at the counseling centre.

"When consultants guide patients, they must tell themeverything and give them all the information they can. Then the patient must choose what to do. Information should be given on how not to transmit the disease if the person wants to sleep with 100 people and have sex. It is not our job to control the behaviour of others. If I go somewhere to have an injection or take a test, I tell them to wear gloves but if they open a file or form wearing gloves, it is done just to offend."

\section{Woman infected with HIV by her husband}

She is a consultant at positive fellowship club; she describes her experience of dealing with patients at the counseling centre.

"Last week the welfare department brought in some children. I went to pick up one of the babies. A woman who was taking blood from patients told me in front of everybody to put the baby down because the baby might become infected and they hadn't yet tested the baby. Attitudes are terrible."

\section{Woman infected with HIV by her husband}

She talks about confirming the rights of patients.

"At the first I used to say I was infected by my husband and I was therefore not considered a "bad person". However, even those considered "bad people" also have problems and may have fallen into this situation or may be drug addicts infected through injection; they are not guilty either. So now when they ask me how I became infected, I say it doesn't matter. What is important is that I am HIV-positive and how I am managing my illness so I can live in a healthy society with my disease. Like other people, I have the right to a normal life and people cannot take this right from me. Unfortunately, we do not know our rights and because of this, people everywhere oppress us."

\section{Young woman infected with HIV by her sexual partner, who injected drugs}

She talks about the problems with staff who take blood.

"We understand why personnel behave badly towards us. When a staff member was taking blood, a doctor talked to me very badly; I never said anything and started crying only after I came out. I even wanted to throw myself under a car. I do not know why she does not do her job. She bothers patients with her behaviour and stigmatizes us. Here we are treated very brutally."

\section{Young girl infected with HIV by injecting drugs at parties}

"I went to a hospital and told the doctor about the problem. He got angry and called the nurse, and washed his hands with alcohol. I felt very ill for a few days and I went to the hospital. I should have been admitted but they told me there were no free beds and to go to another hospital by ambulance, but after 45 minutes they told me the other hospital did not have isolation rooms, and I should go wherever I wanted. When I was leaving, they wanted me to put in writing that I left of my own accord and not to say that they didn't have beds. I didn't agree to this and they argued with me. Wearing gloves is getting to be a normal thing for me; it isn't something that makes me upset. Most people are afraid of us, even educated doctors and other medical staffs have very bad behaviour. I have been sick several times because my immune system is weak. Now, besides the costs, when you go to renew the insurance booklet they tell you how much of the booklet you used in 6 months."

\section{Woman infected with HIV by her husband, who injected drugs}

She talked about the behaviour of specialists with patients in research work.

"Doctors deceive patients; they tell us to do a test, it is free and they will give us the results, but they do not show us any results. Patients are like laboratory mice. Every time they do a test, we ask for the results but staff do not give them. They say the results are in our medical records, but when we look at them, there are no results. We cannot trust them."

\section{Middle-aged man infected with HIV through injecting drug use}

From his point of view, the problems of this group of patients are huge and are related to the health policy of the country.

"The government and the system have as negative image of us. I do not want to make it a political issue but it is a political issue; all our problems go back to the system. The system does not want HIV to be discussed in the media; they do not give information on how to deal with patients. It goes back to the root, that there is no such thing [HIV/AIDS] in an Islamic country; also there are no accurate statistics. The system wants to report the transmission of the disease only - through injecting drug use. The media came here for an HIV anniversary and interviewed me. When I watched a programme on television, I saw all parts with constructive criticism were removed and only one question remained: how did you get infected? Infection by injecting drugs was shown. Imagine you are a television viewer and they say a person got HIV by injecting drugs but they do not talk about the stigma and problems of this person. We are not supported by the organization.

\section{Discussion}

The results of our study show that patients with HIV are faced with many problems when trying to get medical treatment for the disease and other conditions because of stigma, lack of awareness, incomplete information on how the disease is transmitted or intense fear of personnel and health professionals. The behaviour of staff with patients described by our participants can have very dangerous and irreversible consequences for the patient and for society, because these patients may refuse to admit to having the disease and this may allow HIV to be spread further.

At the obstetrics and gynecology department, the most important problems include bad attitudes and 
behaviour of health care workers towards patients, failure to provide medical care from fear of being infected with HIV, the mandatory pledge, which has no legal basis, not to have children, and the lack of patient confidentiality (HIV-positive is written on top of the patient's medical records). The results of a study by Turan et al. (2008) showed that medical personnel have a strong fear of HIV infection in maternity wards and also of stigma because of working with HIV-positive patients in the community (8). An et al. (2015) showed that the lack of friendly and effective medical communications, lack of confidentiality and stigma for HIV patients in women's health services leads to denial of medical assistance and lack of access to health care. Conversely, a good and effective social relationship between health care providers and patients encourages patients to seek treatment and follow-up (9). Women's health services are of particular importance in terms of education on sexual behaviour and pregnancy.

Patients with HIV referred to the departments of medicine and endoscopy/biopsy encountered many problems. When the medical staff were informed that the patients were HIV-positive, they refused to provide medical services, and knowledge about HIV was inadequate, even among experts in the field of HIV infection. Rerknimitr and Kullavanijya (2001) showed that patients with HIV frequently have gastrointestinal problems. The most common symptoms include diarrhoea, esophageal and hepatobiliary symptoms, and weight loss (10). Chong and Lim also reported that demand for endoscopy services is increasing because of the continuing spread of HIV and the incidence of gastrointestinal complications among patients with HIV (11).

In our study, an HIV-positive patient talked about problems after eye surgery that arose because of the specialist's fear of infection. Sharew and Azage in 2015 showed that ocular manifestations are often diagnosed in patients with HIV/AIDS; visual acuity and CD4 counts were independent predictors of ocular manifestations (12).

One of the most painful issues reported by our participants was surgery for patients with HIV, which they were refused by hospitals, by specialists and medical staff. Gansera et al. (2016) in a study in Germany, reported that there is support for not performing cardiac surgery in patients with hepatitis C and HIV infection and a number of patients reported that some hospitals refused to admit them (13). A qualitative study by GwalaNgozo et al. in 2010 held individual interviews with 15 physicians about performing surgery and found four areas of concern in the experiences of surgeons regarding performing surgery on patients with HIV/AIDS: personal factors, patient factors, factors related to the structure of the health system, and factors related to the treatment protocol of patients with HIV/AIDS. Although some surgeons perform surgery on patients with HIV/AIDS, they experienced considerable stress associated with the treatment and care of these patients (14). Studies also suggest that admission of patients with HIV to the surgical ward is not easy, and sometimes surgeons do not want to carry out surgery on these patients for ethical and altruistic issues.

One participant with skin problems complained about the way they were treated and the indifference and irresponsibility of the dermatologist. Cutaneous disorders are prevalent in patients with HIV (15). Given that the incidence of skin manifestations in people with HIV increases as the disease progresses and the immune system becomes weaker, early detection and treatment of skin disorders can improve the quality of life of people with AIDS. With patience and effort, dermatologist can help heal and relieve the skin problems of many patients with HIV.

Another participant mentioned the difficulties faced by patients with HIV when they visited the dentist because of the attitude of dentists. Oral lesions one of the first clinical manifestations in patients with HIV and can help monitor the progress of AIDS. Oberoi et al. (2014) assessed the attitude of dental students towards patients with HIV/AIDS (16). About two thirds (67\%) said they would treat HIV-positive patients. Potential difficulties in providing dental treatment for the HIV/AIDS patients included the attitude of other patients (49.9\%) and fear of staff (52.5\%). Only $15.5 \%$ of the dental students had accurate knowledge and information on infection control (16). Therefore, it is important that dental students, as future dentists, not only have practical skills but also the proper attitude to prepare them for treatment of patients with HIV/AIDS.

Our participants faced many problems in clinics/wards for infectious and behavioural diseases which include:1) bad and inappropriate attitudes and behaviour of medical staff; 2) sense of stigma and discrimination by medical staff; 3 ) lack of accurate and scientific knowledge and information and advice in relation to the disease and its transmission routes; 4) medical staff's lack of education and knowledge related to the disease and its transmission routes; 5) feeling stigmatized by health care staff in all areas of the hospital wearing gloves when dealing with them; 6) attitudes of staff to patients who had been infected by certain routes; 7) abuse of patients in research projects without any results or rewards; 8) stigma because of the religious views within the health system on the disease; 9) having to pay medical expenses that were previously provided free; and 10) lack of care of patients in hospital wards. Rahmati Najarkolaei et al. (2010) explored the perceptions and experiences of 69 people living with HIV at clinics in Tehran in relation to quality of health care and attitudes and behaviour of health care providers (17). Almost all their participants felt stigma and experienced discrimination by health care providers. This was because the health care providers were afraid of being infected with HIV and because of negative attitudes and religious assumptions about the disease. Participants cited at least four main examples of shame and stigma: 1) refusal of care, 2) improper care, 3) excessive precautions and physical distance from the patient, and 4) humiliation and blame. These reactions by health care providers can provoke reactions in patients with HIV/ AIDS such as refusal of care or delay in continuing of care, non-disclosure of illness or HIV status when they return 
to health centres, or use alternative or spiritual treatments. The emotional responses of the patients with HIV to the perceived stigma included: the feeling that they did not deserve care, reduced incentive to be healthy, anger and resentment, and emotional stress (17). While previous studies have shown that many health care providers in the Islamic Republic of Iran had a relatively positive attitude towards people living with $\operatorname{HIV}(18,19)$, the study by Karamouzian et al. in 2015 reported high levels of stigma of HIV patients in Iranian health centres (20). In addition, Tavakol et al. (2012) reported that the stigma associated with AIDS resulted in inappropriate fears in the medical community, which affected the interaction of patients and doctors, and led to treatment discrimination of these patients (21). The results of our study and other studies in the Islamic Republic of Iran all consistently show that patients with HIV experience considerable stigma and discrimination in health care centres, and programmes are needed to reduce them.

\section{Conclusion}

Three decades after the emergence of HIV/AIDS and people with HIV/AIDS still experience social stigma. Despite this and the emphasis of UNAIDS on programmes to reduce stigma, it seems that success has not been achieved in this area. Due to the increase in HIV/AIDS in the country, it is essential for authorities to develop strategies to resolve the problems that patients with HIV/AIDS face in health care centers. Lack of proper planning to provide appropriate health care services in outpatient departments and in hospital has led to the disease not being diagnosed, which has consequences for society. According to the results of our study, the medical problems of these patients can be divided into three areas: 1) providing health care, 2) communication and interaction between patients and medical staff, and 3) lack of or inadequate information of the medical staff about HIV and transmission of the virus. The authorities should determine the health services needed for patients with HIV in all therapeutic areas and should provide them with free health services packages. To improve interaction and communication between health care providers and patients with HIV, interventions are needed to reduce stigma, such as specialized training programmes for health care providers. Staff should be given more education and information about the virus and how it is transmitted. They should also be trained on how to manage patients with HIV and how to give advice on sexual behaviour and ways to prevent pregnancy in order to prevent the spread of HIV. Furthermore, training on the importance of confidentiality and non-disclosure of patient information is needed. A multifaceted package of policies, infrastructure and educational interventions are needed to allow full (medical and psychological) support of patients living with HIV/AIDS. This would lead to better quality of care and quality of life of patients, and help prevent the transmission of HIV.

\section{Acknowledgments}

We thank the Research Deputy of Tehran University of Medical Sciences, Ms Norouzi, Ms Kurdi, and all the personnel of positive fellowship club and behavioral health counselling clinic of Imam Khomeini Hospital for their help in implementing the project.

Funding: The Research Deputy of Tehran University of Medical Sciences funded the study.

Competing interests: None declared.

\section{Je suis séropositif, mais je suis un être humain : étude qualitative sur les expériences de stigmatisation dans les centres de santé en République islamique d'Iran}

\section{Résumé}

Contexte : Les personnes vivant avec le VIH peuvent avoir de nombreux problèmes de santé et faire face à des difficultés lors de la recherche des soins de santé en raison de la stigmatisation et du comportement inapproprié des personnels de santé.

Objectifs : La présente étude visait à évaluer les problèmes rencontrés par les personnes séropositives lorsqu'elles recherchent des soins de santé en République islamique d'Iran.

Méthodes : Une étude qualitative a été menée auprès de 10 personnes vivant avec le VIH, membres du club de soutien aux séropositifs de l'hôpital Imam Khomeini de Téhéran. La participation était volontaire. À l'aide d'une discussion de groupe, les participants ont abordé les problèmes auxquels ils étaient confrontés lorsqu'ils avaient besoin d'accéder aux soins de santé dans les différents services de santé et les dispensaires. Les données ont été analysées en utilisant une analyse inductive de contenu.

Résultats : Les participants ont été confrontés à de nombreux problèmes dans l'ensemble de ces services et dispensaires lorsqu'ils ont eu besoin de soins de santé. Les problèmes les plus importants étaient: 1) le refus de traitement dans les services de consultations externes, les services médicaux et chirurgicaux des hôpitaux;2) le comportement inapproprié des consultants et du personnel médical; et 3) la connaissance insuffisante du personnel médical sur le VIH et son mode de transmission. 
Conclusions : Fournir au personnel médical et aux personnels de santé davantage d'informations sur le VIH et sa transmission, les former au traitement et à la prise en charge appropriée des patients séropositifs et fournir des offres de traitement et de services médicaux gratuits aux personnes vivant avec le VIH sont des solutions qui peuvent contribuer à réduire la stigmatisation et les problèmes auxquels les patients séropositifs sont confrontés lorsqu'ils cherchent à se faire soigner et à améliorer les soins qu'ils reçoivent.

$$
\begin{aligned}
& \text { أنا مصاب بفيروس العوز المناعي البشري، لكني إنسان: دراسة نوعية عن تجارب الوصم في مراكز الرعاية الصحية في } \\
& \text { جمهورية إيران الإسلامية } \\
& \text { نسرين عابدي نيا، مهرناز رسولي نجاد، أحمد نوربالا، بنفشة مور ادمند بديع } \\
& \text { الخلاصة }
\end{aligned}
$$

الخلفية: قد يعاني المصابون بفيروس العوز المناعي البشري مشكلات صحية كثيرة، وقد يواجهون صعوبات عند المبات التهاس الرعاية الصحية بسبب

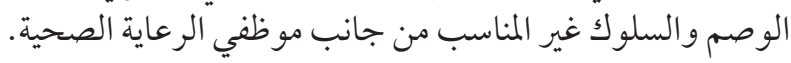

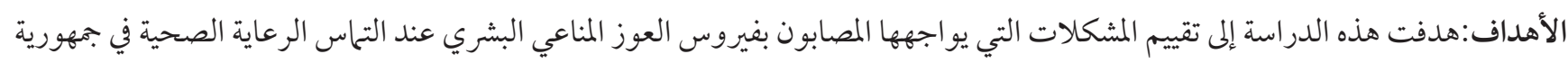
إير ان الإسلامية.

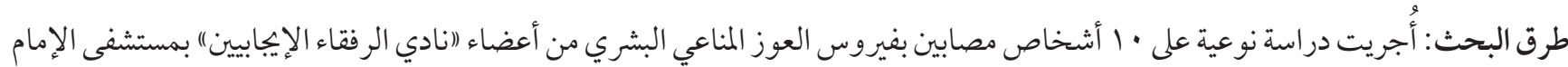



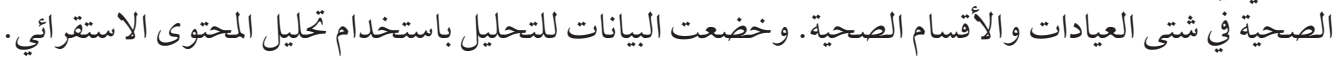

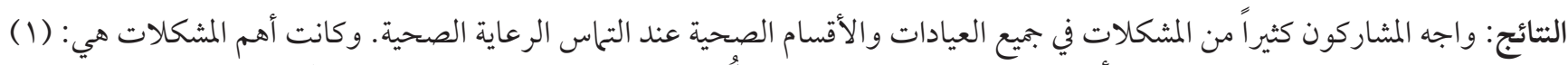

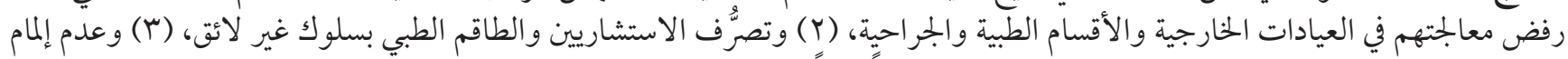
الطاقم الطبي بفيروس العوز المناعي البشري وبكيفية انتقاله إلماماً كافياً.

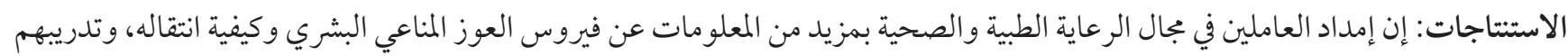

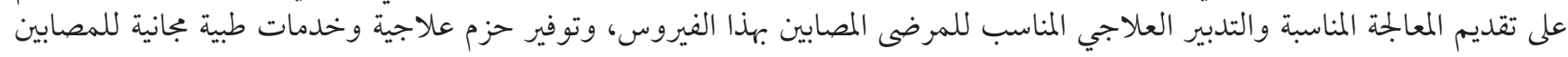

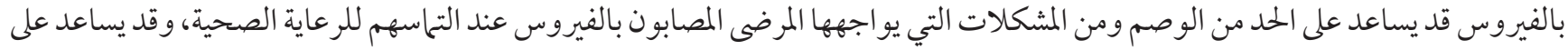
تحسين الرعاية التي يتلقونها.

\section{References}

1. UNAIDS. Country. Islamic Republic of Iran. Overview (http://www.unaids.org/en/regionscountries/countries/islamicrepublicofiran, accessed 3 March 2018).

2. Meshkati M, Hajarian A, Mostaajeran M, Neamatolahi SH, Baadieyan GH, Hosseiny L. [Knowledge and attitudes of health providers about AIDS, Esfahan, 2011.] Iran J Infect Dis. 2013;18(60):47-51. [In Farsi]

3. Afsar Kazerooni P, Heidari AR, Amini Lari M, Mehrab S, Sabet M. Knowledge and attitude of nurses and health care workers about AIDS in Shiraz, south of Iran. Sci J Hamadan Nursing \& Midwifery Faculty. 2008;2(34):28-37. [In Farsi]

4. Ghorbani GH A, Mehrabi Tavana A, Ataee R A. [Knowledge assessment in nurses of Baqiyatallah (a.s.) hospital about AIDS.] J Military Med. 2006;8(2):91-6. [In Farsi]

5. Public health benefits of partner notification for sexually transmitted infections and HIV. Stockholm: European Centre for Disease Prevention and Control; 2013.

6. Seif Farshad M. [Ethics is essential in HIV+ patients.] Medl Ethics J. 2010;4(12):85-106. [In Farsi]

7. Imani MM, Noushadi MR. [Quality content analysis.] Pazhuhesh. 2011-12;3(2):15-44. [In Farsi]

8. Turan JM, Miller S, Bukusi EA, Sande J, Cohen CR. HIV/AIDS and maternity care in Kenya: how fears of stigma and discrimination affect uptake and provision of labor and delivery services. AIDS Care. 2008; 20(8):938-45.

9. An SJ, George AS, LeFevre A, Mpembeni R, Mosha I, Mohan D, et al. Programme synergies and social relations: implications of integrating HIV testing and counselling into maternal health care on care seeking . BMC Public Health. 2015;15:24.

10. Rerknimitr R, Kullavanijaya P. Endoscopy in HIV infected patients. J Med Assoc Thai. 2001;84(Suppl 1):S26-31.

11. Chong VH, Lim CC. Human immunodeficiency virus and endoscopy: Experience of general hospital in Singapore. J Gastroenterol Hepatol. 2005;20(5):722-6.

12. Sharew G, Azage M. Predictors of HIV/AIDS related ocular manifestations among HIV/AIDS patients in Felege Hiwot referral hospital north-west Ethiopia. J Ophthalmol. 2015;2015:965627. 
13. Gansera LS, Eszlari E, Deutsch O, Eichinger WB, Gansera B. High-risk cardiac surgery in patients with intravenous drug abuse and/or active hepatitis C or HIV infection: an ethical discussion of six cases. Thorac Cardiovasc Surg. 2016;64(1):2-5.

14. Gwala-Ngozo J, Taylor M, Aldous C. Understanding the experiences of doctors who undertake elective surgery on HIV/AIDS patients in an area of high incidence in South Africa. African J AIDS Res. 2010;9(1):11-6.

15. Navarrete-Dechent C, Ortega R, Fich F, Concha M. Manifestaciones dermatologicas asociadas a la infeccion por VIH/SIDA [Dermatologic manifestations associated with HIV/AIDS]. Revista Chilena Infectol. 2015;32(Suppl 1):S57-71.

16. Oberoi SS, Marya CM, Sharma N, Mohanty V, Marwah M, Oberoi A. Knowledge and attitude of Indian clinical dental students towards the dental treatment of patients with human immunodeficiency virus (HIV)/acquired immune-deficiency syndrome (AIDS). Int Dental J. 2014;64(6):324-32.

17. Rahmati Najarkolaei F, Niknami S, Aminshokravi F, Bazargan M, Ahmadi F, Hadjizadeh E, Tavafian SS. Experiences of stigma in healthcare setting among adults living with HIV in the Islamic Republic of Iran. J Int AIDS Soc. 2010;22(13):27.

18. Alipour Z, Eskandari N, Mokhah S. [Evaluation of knowledge and attitude of non-medical students about AIDS.] Quarterly J Holistic Nursing and Midwifery. 2016;25(79):10-20. [In Farsi]

19. Etemad K, Eftekhar Ardabili H, Rahimi A, Gouya M, Heidari A, Kabir M. [Attitudes and knowledge of HIV positive persons and high risk behaviors groups in Golestan, Iran.] Iranian J Epidemiol. 2011;7(1):23-31. [In Farsi]

20. Karamouzian M, Akbari M, Haghdoost AA, Setayesh H, Zolala F. [“I am dead to them": HIV related stigma experienced by people living with HIV in Kerman, Iran.] J Assoc Nurses AIDS Care. 2015;26(1):46-56. [In Farsi]

21. Tavakol M, Nick Ayen D. [Stigmatization, doctor-patient relationship, and curing HIV/AIDS patients. Bioethics J. 2012;2(5):11 743. [In Farsi] 